Іаанна Васілюк

Беласток

\title{
Шляхі фарміравання нацыянальнай ідэі ў беларускай літаратуры XIX стагоддзя
}

Станаўленне новай мастацкай традыцыі ў беларускай літаратуры XIX стагоддзя напрамую звязана з абуджэннем нацыянальнай свядомасці. Якраз у гэты час адбываецца этнакультурная кансалідацыя беларускага народа, фарміраванне беларускай нацыі. Нарэшце пачынаецца эпоха нацыянальнага Адраджэння, якая знамянуецца зваротам да нацыянальных каранёў, самабытнай культуры беларускага народа, яго спрадвечнай мовы. Пачынальнікі новай мастацкай традыцыі, усведамляючы сябе спадчыннікамі слаўнай у не такім ужо далёкім мінулым дзяржавы, імкнуліся абудзіць гэтую свядомасць у сваім народзе.

Ужо напрыканцы XIX стагоддзя самаахвярны падзвіжнік на ніве беларускай культуры, добра вядомы ў шырокіх грамадска-культурных колах Беларусі, Польшчы, Расіі, Украіны, Аляксандр Ельскі ў артыкуле "Адам Міцкевіч на Беларусі" (1883), улічваючы рэаліі ўжо сыходзячага стагоддзя, спрабуе ўсвядоміць гістарычны сэнс нацыянальнай ідэі:

Калі заходзіць гаворка пра Міцкевіча і яго сціплае роднае гняздо, міжвольна паўстае пытанне, чаму гэта столькі карыфеяў айчыннай навукі і мастацтва, чаму гэтакіх Хадкевічаў, Багушэвічаў, Манюшкай, Міцкевічаў, Чачотаў, Кандратовічаў, Занаў, Дамейкаў, Здановічаў, Прозараў, Барташэвічаў, Семірадскіх, Крашэўскіх і столькі-столькі іншых выдала адна зямля. Павінна гэта сапраўды быць глеба ўрадлівая, калі нараджае такія шчодрыя плёны! (...)

Бо старажытны ж народ гэты, што насяляе разлеглыя абшары: ад вытокаў Дняпра і да Буга і Нарава, ад Віліі да Прыпяці - гнязда старадаўняй славяншчыны, краіна герояў, гуслярой, патрыяхальных ад- 
носін і ахвяр у імя ўзнёслых ідэалаў! Усё гэта разам узятае злілося ў духу карэннага племені (...). Нездарма ж пра гэтую родную зямлю, пачынаючы ад Баяна аж да нашых часой, столькі разой з захапленнем спявалі нашы вестуны, чэрпаючы з народных песень, легенд і паданняў прарочае натхненне ${ }^{1}$.

Задаючыся рытарычным пытаннем, А. Ельскі сам жа адказвае на яго ў сцісла-ўзнёслай форме. Бо перад ім, гісторыкам, этнаграфам, эканамістам, пісьменнікам, здаўна былі адкрыты гістарычныя далягляды культурна-духойнага развіцця Беларусі. Так, несумненна, што А. Ельскі быў добра знаёмы з трыма рэдакцыямі Статутаў Вялікага Княства Літойскага.

У прадмове ж да Статуту 1588 года канцлер Вялікага Княства Літойскага Леў Сапега з гонарам пісай: Не обиим яким языком, але своим власным права списаные маем и каждого часу чаго нам потреба ку опору всякое крывды ведати можем². На старабеларускай мове, якая з'яўлялася афіцыйнай мовай тагачаснай вялікай еўрапейскай дзяржавы, ствараліся дасканалыя юрыдычныя дакументы, перакладаемыя адразу і на лаціну, і на польскую мову. Невыпадкова Адам Міцкевіч у сваіх парыжскіх лекцыях аб славянскіх літаратурах, прачытаных у Каледж дэ Франс, выказаўся такім чынам пра беларускую мову: Narzeczem Białej Rusi, nazywany ruskim lub litewsko-ruskim (białoruskim), mówi (...) mniej więcej 10 milionów; jest to narzecze najbogatsze i najczystsze; było ono niegdyś uprawne: za czasów odrębności Litwy wielcy książęta postugiwali się nim w korespondencji dyplomatycznej ${ }^{3}$. I далей: Status Litewski pisany jest jezykiem, najharmonijniejszym i najmniej skażonym ze wszystkich dialektów stowiańskich ${ }^{4}$.

Складаныя сацыяльна-палітычныя ўмовы XVII-XVIII стагоддзяу прычыніліся да заняпаду беларускамоўнай літаратурнай творчасці. Мова шэрагу летапісай, Статутай Вялікага Княства Літойскага, прадмоў і перакладу Святога Пісання, ажыццёўленага вялікім асветнікам Францішкам Скарынам, уступае сваё законнае месца лаціне і пальшчызне, а пасля рускай мове. У 1696 годзе Сейм прымае пастанову, якая забараняе выкарыстанне беларускай мовы $\ddot{\mathrm{y}}$ афіцыйнай

1 А. Ельскі, Адам Мічкевіч на Беларусі, [у:] Аляксандр Ельскі, Вьъбранае, Мінск 2004 , с. 321.

2 Cтатут Вялікага Княства Літоўскага 1588. Тэксты. Даведнік. Каментары, Мінск 1989, с. 48.

3 A. Mickiewicz, Dzieła. Wydanie narodowe, Warszawa 1955, t. VIII, s. 100.

4 Tамсама, c. 106. 
перапісцы, у дзяржаўных установах. Спыняецца друкаванне кніг на беларускай мове і такім чынам занепадае высокая традыцыя беларускага пісьменства, сфарміраваўшаяся на працягу XI - першай паловы XVII стагоддзяў.

У апошняй чвэрці XVIII стагоддзя ў выніку трох падзелаў Рэчы Паспалітай беларускія землі далучаюцца да Расіі. Палітыка царызму адмайляла не толькі дзяржаўную незалежнасць, але і культурна-этнічную самабытнасць беларусаў. Мікалай I, наклайшы ў 1840 годзе вета на дзеянне Статуту Вялікага Княства Літойскага, увогуле забараняе карыстацца тэрмінам "Беларусь", які ў 30-40-х гадах XIX стагоддзя пачаў пашырацца як назва значнай часткі ВКЛ. Вызначаючы Беларусь як "Северо-Западные губернии", царызм спадзяваўся зрабіць яе сваёй спаконвечнай уласнасцю, часткаю расійскай імперыі. Такім чынам на працягу 30-40-х гадоў, па словах літаратуразнаўцы Міколы Хаўстовіча, склалася сітуацыя, калі: Адсутнасиь палітьчнае ды нацьянальнае незалежнасиі, нядобразычлівыя, а часам $і$ непрьлзньяя адносінь суседзяў не давалі мажлівасиі ўжо народжанай беларускай нацьянальнай ідэі змагациа за развіциё, за станаўленне нацьі ${ }^{5}$.

Аднак, нягледзячы на, здавалася б, цалкам неспрыяльныя ўмовы, напачатку XIX стагоддзя распачынаецца беларускае нацыянальнае Адраджэнне. Па словах філосафа, літаратуразнаўцы Уладзіміра Конана: На першае месца выходзячь праблемь наиьянальнай самабьтнасиі мастацтва, альтэрнатьйныя думкі пра магчьмасць стварэння новай y Еўропе беларускай літаратурьъ 6 I трэба падкрэсліць, што ў значнай ступені беларуская нацыянальная свядомасць фарміравалася, кшталтавалася пісьменнікамі, якія сталіся сапраўднымі будзіцелямі свайго народа. На асаблівую патрыятычную ролю літаратур прыгнечаных нацый звярнуў у свой час увагу беларускі літаратуразнаўца Алесь Яскевіч: Возрождаясь на пафосе утверждения сочиально-демократической идеи, самобытного наиионального достоинства и, не успев даже как следует определиться в своем профессиональном статусе, они сразу брали на себя роль народных заступников, искателей неотложного вьхода из национального тупика, в котором находился народт.

\footnotetext{
5 М. Хаўстовіч, Ян Баршчэўскі $і$ літаратурна-грамадскі рух на Беларусі $\check{y}$ 3040-я ге. ХІХ ст., [у:] Шляхамі стагоддзяў, Мінск 1992, с. 121.

6 У. Конан, Гісторыя эстэтычнай думкі Беларусі. У 3-х тамах, Мінск 2010, т. 1, c. 330 .

7 А. Яскевич, Становление белорусской художественной традиции, Минск 1987, c. 217 .
} 
Літаратурнаю моваю Беларусі пачатку XIX стагоддзя з'яўлялася польская: яна была моваю касцёла, справаводства, а найперш - моваю школы. Беларускае слова пераважна жыло у ніжэйшых слаях грамадства, пад саламянымі стрэхамі. Пры ацэнцы ж прыналежнасці пісьменніка да той ці іншай літаратуры доўгі час традыцыйна пад увагу звычайна бралася адно мова яго твораў. У выніку на працягу XIX-га стагоддзя беларуская літаратура перыяду фарміравання новай мастацкай традыцыі, а таксама літаратура Пераходнага перыяду (другая палова XVII-XVIII стагоддзя), была прадстаўлена толькі беларускамоўнай творчасцю. Аднак у апошнія дзесяцігоддзі беларускім літаратуразнаўствам пераканаўча даведзена, што творчая спадчына Яна Чачота, Яна Баршчэўскага, Уладзіслава Сыракомлі, Вінцэнта Дуніна-Марцінкевіча, Вінцэся Каратынскага і іншых належаць у першую чаргу беларускай літаратуры, а яны з'яўляюцца польска-беларускімі ці беларуска-польскімі пісьменнікамі.

Між тым, варта ўзгадаць, што гэты тэрмін уведзены у навуковы ужытак якраз польскім даследчыкам Юзафам Галомбкам ${ }^{8}$ на пачатку 30-х гадоў XX стагоддзя. Ды у айчынным літаратуразнаўстве ён не набыў распаўсюджання. У даследаваннях польскіх аўтараў радзіму паэтаў і пісьменнікаў XIX стагоддзя, народжаных на даўніх землях Вялікага Княства Літойскага, прынята называць, Kresami, a ix літаратуру - kresowa. Праўда, польскія літаратуразнаўцы ўжо ў 30-я гады XIX стагоддзя звярнулі ӱвагу на рэгіянальную адметнасць літаратурнага працэсу на тэрыторыі даўняй Рэчы Паспалітай. Наступным крокам была спроба асэнсавання месца літаратуры крэсаў у польскім прыгожым пісьменстве. У выніку ӱзнікла вызначэнне літаратурныя школьl. Крытэрыем, што прадвызначыў прыналежнасць твораў да польскай літаратуры, стала мова. Апрача таго браўся пад увагу падтэкст ідэі адбудовы Рэчы Паспалітай.

Першаю была сфарміравана ліщвінская школа, а затым польскамоўныя пісьменнікі, што паходзілі з Украіны, былі аб'яднаны ва ўкраінскую школу. Такім чынам: Літаратурны працэс, які не ўпісваўся ў рэчышча уัласнапольскай літаратуры, пачаў далучачиа да яе кантэксту з дапамогаю панячия «школа»9. Аднак самі літаратары не лічылі сябе прыналежнымі да якой-небудзь школь: яны былі

8 J. Gołąbek, Wincenty Dunin-Marcinkiewicz - poeta polsko-białoruski, Wilno 1932, s. 19.

9 М. Хаўстовіч, Ад “беларускай школье" ў польскай літаратурь - да беларускай польскамоўнай літаратуры, "Беларусіка = Alberuthenica", Мінск 2001, кн. 20, с. 169. 
паэтамі і пісьменнікамі Літвы-Беларусі. Па той жа прычыне не было у той час гаворкі пра беларускую школу. Даследчыкі літаратуры лічаць, што тэрмін беларуская школа ў дачыненні да літаратурнага жыцця Беларусі XIX стагоддзя першы ӱжыў і апрацаваў у 30-я гады XX стагоддзя Станіслаў Станкевіч. Па аналогіi з украінскай школаю вучоны прапанаваў аднесці да беларускай школь творчасць беларускіх літаратарай, што пісалі па-польску і у творчасці якіх адлюстраваны быт, характар і светапогляд беларусаў${ }^{10}$. У сваю чаргу адзін з найаўтарытэтных даследчыкаў спадчыны беларуска-польскіх пісьменнікаў Уладзімір Мархель у 90-я гады мінулага стагоддзя давёў няслушнасць ужывання паняцця беларуская школа, бо яно ўзнаўляе бачанне гэтай гістарычнай з'явы як часткі польскай літаратуры $i$ перадае толькі польскі бок яе ўспрымання ${ }^{11}$.

На жаль, сталася так, што напрыканцы XIX - значнай часткі XX стагоддзя стэрэатыпнае ўспрыманне твораў паводле іх моўнай прыналежнасці блакіравала раскрыццё беларускіх нацыянальных рысаў у польскамоўнай літаратуры Беларусі. Аднак: Наџылнальная прыналежнасць пісьменніка фіксуечиа не толькі ў мове, але $i$ ў мностве іншых кампанентаў твора ${ }^{12}$. Функцыі нацыянальнага выконвае між тым не столькі мова, колькі змест таго, што яна адлюстройвае ў мастацка-эстэтычнай матэрыі. Польскамоўныя творы, у якіх дамінуе літоўская, украінская ці беларуская праблематыка, практычна належаць да чатырох літаратур: з польскай літаратурай яны былі роднасныя праз мову, а з астатнімі іх аб'ядноўвалі: problematyka, ideowe nachylenie, litewski albo ruski patriotyzm (... $)^{13}$, - лічыць Баляслаў Гадачак. У. Мархель у сваю чаргу пераканаўча сцвярджае: Творы, якія былі напісаны па-польску ауттарамі, этна-генетычна звязаньмі з Беларуссю, уваходзяць у гісторыю беларускай літаратуры як яе польскамоўная пльинь ${ }^{14}$. На яго думку: Гэтая літаратурная спадчына, як адна рука, на якую, каб наблізічиа да аб'ектьіунасиі, трэба глядзеиь з двух бакой - беларускага і польскага. Пальиь яе сиіснуты ў кулак, і мы бачвим толькі яго знешні бок - польскамоўную абалонку, а далонь будзе

10 S. Stankiewicz, „Szkoła białoruska” w polskiej literaturze romantycznej, „Przegląd Wileński", 1933, nr 2, 4, 5.

11 У. Мархель, Прысутнасць былога. Нарысыь, артыкульи, эсэ, Мінск 1997, с. 15.

12 Тамсама, с. 3.

13 B. Hadaczek, Historia literatury kresowej, Kraków 2011, s. 88.

14 У. Мархель, Прысутнасиь былога, с. 14. 
схавана да таго часу, пакуль кулак не расиіснециа $i$ не выпрастуючиа пальиьи, гэта значьць пакуль не будзе выьвчаны беларускі пачатак y гэтай літаратурьв ${ }^{15}$. Літаратурная спадчына Рэчы Паспалітай, якая была $\breve{y}$ сваёй аснове поліэтнічнаю дзяржаваю, у значнай ступені належыць, акрамя палякай, і беларусам, літойцам, украінцам.

Аксіёмай бачыцца тое, што вяртанне гістарычнай памяці і духоўнай спадчыны беларускага народа сталася пабуджальна-стваральным імпульсам для творчасці, а творчасць у сваю чаргу далей фарміравала нацыянальную ідэю, самасвядомасць. Ідэя ж нацыянальнага адраджэння, як і светапоглядная, і мастацка-эстэтычная дамінанта, з'яўляецца фактам мастацкай структуры ці не кожнага твора. Нацыянальны светапогляд, як адзначае Любой Уладыкойская: (...) гэта рэальнь светапогляд, нащьянальнь ў тьлм сэнсе, што менавіта прьналежнасць яго носьбіта да пэуัнай нащьлнальнай культуры надае яму канкрэтныл, своеасаблівы змест $і$ рыссы, што фармірующь спецьлфіку тлумачэння $i$ асэнсавання навакольнага свету ${ }^{16}$.

У сілу спецыфікі сацыяльна-гістарычнага развіцця Беларусі менавіта народная творчасць у гэты час аказваецца асноваю для фарміравання новай мастацкай традыцыі. Так, Алесь Яскевіч сцвярджае: Фальклор в этот период - пока единственный наличный опьт наиионального эстетического высказывания и, кроме него, первым поэтам негде брать уроки вьражения национальньх форм на родном языке 17. Сапраўды, у складаных сацыяльна-гістарычных умовах тагачаснай Беларусі народная творчасць была амаль адзіным сродкам эстэтычнага адлюстравання рэчаіснасці. На лёсаносную ў працэсе станаўлення літаратуры ролю народнай творчасці звяртае ўвагу Васіль Ліцвінка: Сукупнасиь зместу, шматстайнасць відаў $i$ мастачкіх формаў фальклору, яго уัнутранья $i$ знешнія сувязі ўяўляюиь сабой народную мастачка-філасофскую сістэму. У мастачкіх вобразах, мове, жанравай вызначальнасиі з'яў фальклору знайшлі ўвасабленне духоўныя асновь жьция, маральна-этылчнь кодэкс, прадуктыутны вопьлт абрадава-праиойнай, сямейнай дзейнасиі народа ${ }^{18}$.

15 Тамсама, с. 15.

16 Л. Уладыкойская, Духойныя ідэаль ў сучаснай культурь Беларусі $і$ каштойнасиі глабалізму, Мінск 2009, с. 142.

17 А. Яскевич, Становление белорусской художественной традиции, с. 195.

18 В. Ліцвінка, Самабытнасць беларускага фальклору і яго месца у нацыянальныл Адраджэнні, "Беларусіка = Albaruthenica", Мінск 1993, кн. 1, с. 210. 
Пачатковы этап беларускага нацыянальнага адраджэння прадстаўлены трыма кірункамі - літвінскім (з варыянтам славяна-крывіцкай канцэпцыі) і беларускім ${ }^{19}$, а таксама беларуска-літвінскім ${ }^{20}$. Літвінскі кірунак быў звязаны галоўным чынам з дзейнасцю Віленскага ўніверсітэта і рэалізаваўся найперш у творчасці філаматаў і філарэтаў - Адама Міцкевіча, Яна Чачота і іншых, а пазней, можна сказаць, першага беларускага прафесійнага пісьменніка Вінцэнта Дуніна-Марцінкевіча. Беларускі кірунак аформіўся ў паўночна-ўсходняй Беларусі, у Віцебскай і Полацкай губернях і прадстаўлены найперш творчасцю Яна Баршчэўскага, Арцёма Вярыгі-Дарэўскага. Да беларуска-літвінскага кірунку сярод пачынальнікаў новай беларускай літаратуры належылі Уладзіслай Сыракомля і Вінцэсь Каратынскі.

У апошнія дзесяцігоддзі беларускае літаратуразнаўства належным чынам ацаніла ролю Яна Чачота $\ddot{y}$ фарміраванні нацыянальнай свядомасці. Ён, як патрыёт роднай зямлі, усведамляў значэнне слаўнай гісторыі народа ў фарміраванні асобы і нацыі, быў захоплены гісторыяй Вялікага Княства Літоўскага, у выніку чаго і ўзнік ягоны гістарычны эпас беларусаў. Ян Чачот з'яўляецца адным 3 найвыдатных пачынальнікаў новай беларускй літаратуры - першым беларускім фалькларыстам, які не толькі збіраў, але і выкарыстоўваў фальклор у сваіх творах. Ён глядзей на беларускую народную творчасць вачамі паэта і этнографа, а яго дасягненні ў галіне даследавання духоўнай спадчыны беларускага народа сталі піянерскімі для далейшага развіцця фалькларыстыкі беларусаў. Значную частку літаратурнай спадчыны Чачота складаюць балады, напісаныя на польскай мове у 1818-1819 гадах. Алесь Яскевіч адзначыў, што польский же язык в данном случае лишь оболочка выражения, вынужденная запретом языка родного, да к тому же еще не вполне выкристаллизовавшегося из устного, чтобы служить средством поэтического высказывания ${ }^{21}$. Ян Чачот ажыццявіӱ выданне шасці кніг беларускіх народных песень з-пад Дзвіны і Нёмана.

Варта падкрэсліць, што ўвага да народнай творчасці, збіранне яе, выкарыстанне ва ўласных творах - своеасаблівая мадэль развіцця беларускай свядомасці і беларускага прыгожага пісьменства ў перыяд фарміравання новай мастацкай традыцыі, аб чым сведчыць дзейнасць і Яна Чачота, і іншых пачынальнікаў новай беларускай літаратуры.

19 У. Конан, Гісторыя эстэтьинай думкі Беларусі, с. 331.

20 Тамсама, с. 350.

21 А. Яскевич, Становление белорусской художественной традиции, с. 52. 
Згодна слоў Уладзіміра Калесніка: (...) у польскую літаратуру чераз беларускі фальклор уваходзілі многія мастакі слова, а народныля паданні і песні былі ўведзень у ранг нацыянальнага мастацтва, сталі апорнымі пунктамі начьиянальнай свядомасиі $i^{22}$.

Беларускія народныя матывы выкарыстоўваў у сваіх творах і Адам Міцкевіч. Сваім падыходам да гісторыі і лакальным беларускім зместам, укаранёнасцю ў народную паэтычную культуру, сваімі вобразамі старадаўняй Літвы творчасць вялікага паэта аказала агромністы ўплыў на станаўленне новай беларускай літаратуры і выпрацойку беларускай нацыянальнай ідэі. Заслугоўвае ўвагі сцвярджэнне Віктара Каваленкі аб тым, што Мічкевіч звяртаўся да роднай беларускай зямлі як да прадмета паэзіi, чэрпаючь ў ёй натхненне не пад начіскам знешніх жыциёвых прычын, а па адзінаму загаду паэтавага сэрча ${ }^{23}$. Паэт, як ужо згадвалася, цаніӱ беларускую мову, называючы яе самай гарманічнай і з усіх славянскіх моў найменш змененай.

Найяркім прадстаўніком беларускага кірунку на пачатковым этапе беларускага нацыянальнага Адраджэння быў Ян Баршчэўскі. Яго цікавасць да мясцовага фальклору выявілася у напісаных па-польску фантастычных апавяданнях, сабраных у адной кнізе пад загалоўкам "Шляхціц Завальня або Беларусь у фантастычных апавяданнях". Кніга Яна Баршчэўскага стала значнаю вехаю на шляхах фарміравання беларускай нацыянальнай свядомасці і дасюль захойвае сваю актуальнасць. Ян Баршчэўскі разумеў, што ў народнай традыцыі захоўваюцца спрадвечныя ісціны, выяўляецца ментальнасць народа і ўрэшце - беларускі архетып. Менавіта specyficzne odbicie w literaturze mentalności chtopskiej przyniosło $w$ rezultacie $i$ te elementy historycznie uksztaltowane, które potwierdzaly stopniowe dochodzenie chtopstwa do rozumienia spraw narodowych $i$ potwierdzenia własnej odrębności spotecznej24. Якраз у асэнсаванні мінулага краіны Ян Баршчэўскі знайшоў карані тых асноў, якія абумоўліваюць існаванне народа. У неспрыяльных сацыяльна-палітычных умовах, калі забараняецца ўжываць сам тэрмін "Беларусь”, пісьменнік выносіць гэтую назву ў загаловак свайго твора, што надае яму яшчэ большую нацыянальную афарбойку. Усвядоміўшы, што чытацкую беларускамойную аўдыторыю трэба яшчэ ствараць, Ян Баршчэўскі звярнуйся да творчасці на польскай мове, тагачаснай

\footnotetext{
22 У. Калеснік, Тварэнне легенды, Мінск 1987, с. 247.

23 В. Каваленка, Вытокі. Упльвыь. Паскоранасиь, Мінск 1975, с. 65.

24 J. Detko, Literatura - los narodu - świadomość narodowa, [w:] Historia i świadomość narodowa, pod red. Włodzimierza Wesołowskiego, Warszawa 1970, s. 66.
} 
літаратурнай мове Беларусі. Гэтая кніга была адрасавана найперш адукаваным суайчыннікам пісьменніка, якія страцілі нацыянальную свядомасць. Для таго, каб народ усвядоміӱ сваю цэласнасць, з яго ж шэрагаў мусяць быць рэкрутаваны асобы, здольныя зразумець магчымасці і патрабаванні часу. Таму Ян Баршчэўскі піша свой твор на польскай мове, каб свядомасць і імкненне да волі ахапілі як найшырэйшыя колы народа. Бо як дакладна выказаўся філосаф Вінцэнт Гадлеўскі, пры свядомасиі народ $i$ начья - адно 25 .

Можна сказаць, што у значнай ступені дзякуючы менавіта Вінцэнту Дуніну-Марцінкевічу жывая беларуская мова шматмільённага народа стала мовай мастацкай творчасці. Асэнсаванне пісьменнікам рэчаіснасці на беларускай зямлі першай паловы XIX стагоддзя было вызначана асветніцкім і рамантычным успрыманнем свету і мела пераважна фальклорна-этнаграфічны характар. Вінцэнт Дунін-Марцінкевіч адчуваў, што ў малюнках побыту, звычаяў, сялянскай паўсядзённасці схаваны пачатак беларускай літаратуры ${ }^{26}$. У творчасці пісьменніка выдзяляюцца два перыяды, істотна важныя і для развіцця Беларусі: дарэформенны і паслярэформенны. Пісьменніку ўдалося стварыць яскравыя вобразы нацыянальнага характару беларусаў у літаратуры XIX стагоддзя. Па сутнасці, у яго творчасці ўпершыню быў вызначаны дэмакратычны шлях усёй нацыянальнай літаратуры XIX - пачатку XX стагоддзя: абарона жыццёвых інтарэсай беларускага народа, яго правоў на свабоду, захаванне і развіццё нацыянальнай культурнай спадчыны.

Сярод пачынальнікаў новай мастацкай беларускай традыцыі ў беларуска-літвінскім кірунку асаблівае месца належыць Уладзіславу Сыракомлю і яго вучню-паслядоўніку Вінцэсю Каратынскаму. Творчая спадчына паэтай у значнай ступені прасякнута духам народа, сярод якога яны нарадзіліся. Яны запазычалі 3 фальклору матывы і сюжэты, апрацоўвалі песні, у сваіх гутарках, вершах і паэмах выкарыстойвалі народныя прыказкі, прымаўкі. У іх паэзіі фальклорная стыхія выяўлялася, як відаць, па-рознаму, але заўсёды была скіравана на абуджэнне нацыянальнай свядомасці. Галоўнымі героямі твораў У. Сыракомлі і В. Каратынскага былі простыя людзі, сяляне. Chtopstwo, - сцвярджае Юзаф Хлябоўчык, - to potencjalna baza spoteczna pro-

25 http://jivebelarus.net/history/faces/priest-vincent-hadleuski-philosophic-bases-ofbelarusian-idea.html\#literature_src_12, В. Гадлеўскі, Народ - нацыля, "Народны фронт", Мінск 1939, № 5, с. 39.

26 І. Навуменка, Вінцэнт Дунін-Мариінкевіч, Мінск 1992, с. 216. 
cesu narodotwórczego 27 . Паэты бачылі у сялянах прыхаваную мужнасць і ўнутраную прыгажосць. Яны імкнуліся высветліць маральныя якасці чалавека працы, узвысіць яго сумленнасць і працавітасць, паказаць, што праўдзівай высакароднасцю надзелены якраз просты народ, які таксама заслугойвае зямнога шчасця. Творчы метад абодвух паэтай, адпаведна шляхціца і селяніна, быў блізкі рэалістычнаму асэнсаванню рэчаіснасці. Несумненна, яны разумелі патрэбу абуджэння самасвядо-

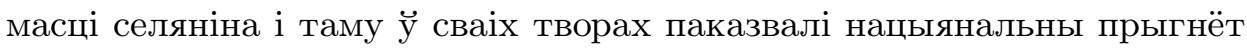
беларускага народа $\ddot{y}$ цеснай сувязі з яго сацыяльным уціскам.

Эвалюцыя беларускага нацыянальнага адраджэння выяўляецца ў лёсах і творчасці многіх пісьменнікаў тагачаснай Беларусі. Адным 3 цэнтральных і трагічных звенняў палітычнага і духоўнага адраджэння беларусаў было Студзеньскае паўстанне 1863 года.

Пасля сялянскай рэформы 1861 года, якая ў значнай ступені адабрала ў сялян надзею на паляпшэнне жыццёвых варункаў, у Беларусі і Літве пачаліся бурныя выступленні у падтрымку вызваленчага руху на тэрыторыі Польшчы. Кіраўніком паўстання 1863-1864 гадоў на землях былога Вялікага Княства Літоўскага стаў малады рэвалюцыянер Кастусь Каліноўскі. Найлепшай формай дзяржаўнага ўладкавання ён лічыў дэмакратычную рэспубліку, марыў пра роўнасць, распаўсюджванне адукацыі і культуры ў народзе, прызнаваў права народа на самавызначэнне. Свае ідэалы ён выказаў таксама і у мастацкай творчасці. Кастусь Каліноўскі вядомы ў літаратуры як аўтар першай нелегальнай беларускамоўнай газеты "Мужыцкая праўда" і палымянага запавету-трыпціху "Лісты з-пад шыбеніцы", напісанага ім напярэдадні смерці ӱ віленскім астрозе.

Паказваючы сялянству шлях да вызвалення, публіцыст пастаянна падкрэслівае, што яно магчымае толькі пры актыўным удзеле самога сялянства у барацьбе. Dopiero szerszy udziat mas ludowych, - піша гісторык літаратуры Ян Дэтка, - przejęcie przez te klasy odpowiedzialności za losy całego narodu, aktywne właczenie się ich przedstawicieli w zarzadzanie krajem $i$ wspótdziałanie $w$ jego istotnych sprawach - nadało catemu procesowi ksztaltowania się świadomości narodowej nie tylko klasowy, ale i równocześnie ogólnonarodowy charakter ${ }^{28}$. Кастусь Каліноўскі верыў у сэнс і паспяховасць рэвалюцыі, бачыў у ёй будучыню сваёй краіны.

27 J. Chlebowczyk, O prawie do bytu małych i młodych narodów, Warszawa - Kraków 1983, s. 196.

28 J. Detko, Literatura - los narodu - świadomość narodowa, [w:] Historia i świadomość narodowa, pod red. Włodzimierza Wesołowskiego, s. 64-65. 
На жаль, 1863 год адбіўся негатыўна на маладой беларускай літаратуры, на дзесяцігоддзі спыніӱ яе развіццё. Пасля паражэння Студзеньскага паўстання царская ўлада жорстка расправілася 3 яго уддзельнікамі. Знішчаліся mblя, - як зазначае Адам Мадьдзіс, - xmo стаў або мог стаць иветам беларускай нацыі ${ }^{29}$. Памёр Уладзіслаў Сыракомля; Вінцэсь Каратынскі пераехаў на сталае жыхарства ў Варшаву; у Сібір быў вывезены Арцём Вярыга-Дарэўскі; Вінцэнт Дунін-Марцінкевіч аказаўся пад паліцэйскім наглядам; ад пераследу за ўдзел у паўстанні схаваўся на Украіне Францішак Багушэвіч. Царская ўлада, якая глядзела на збройнае выступленне як на інтрыгу палякай, у 1867 годзе афіцыйна забараняе беларускі друк (лацінкай).

Такім чынам, падаўленнем паўстання 1863 года пад кіраўніцтвам K. Каліноўскага закончыўся своеасаблівы першы этап нацыянальнага Адраджэння у у XIX стагоддзі. I менавіта з творчасці Францішка Багушэвіча, касіянера $\ddot{\mathrm{y}}$ атрадах К. Каліноўскага, пачалася другая хваля гэтага адраджэнскага руху, скіраванага на абуджэнне нацыянальнай самасвядомасці народа, развіццё яго мовы, літаратуры, іншых відаў мастацтва, грамадскай думкі, на стварэнне незалежнай дзяржавы.

Францішак Багушэвіч - першы вялікі беларускі паэт, які з самага пачатку творчасці ўсведамляў сябе належным да нацыянальнага паэтычнага свету і раскрыў найбольш істотныя і трагічныя з'явы нацыянальнай рэчаіснасці. Менавіта яму належыць гонар выпрацойкі сутнасных ідэй беларускага адраджэння: узвелічэнне мовы народа як асноватворнай духоўнай каштойнасці, абуджэнне гістарычнай свядомасці як неабходнай умовы годнага самапачуцця, вызначэнне тэрыторый, населеных здаўна беларускім этнасам.

Канцэпцыя нацыянальнага жыцця была выказана Ф. Багушэвічам найперш у яго паэтычных кнігах "Дудка беларуская" (1891) і "Смык беларускі" (1894). Абедзве прадмовы Ф. Багушэвіча да гэтых кніг своеасаблівае падвядзенне вынікаў пакутлівых пошукаў паэта і яны ж - дэкларацыі, маніфесты беларускага рэвалюцыйнага і нацыянальна-вызваленчага руху, беларускай дэмакратычнай літаратуры

Паэт Белай Русі$^{30}$ (Францішак Багушэвіч) паслядоўны ў вобразным, эстэтычна-мастацкім разгортванні беларускай нацыянальнай ідэі, яго палымяная любоў да народа і Радзімы выяўляецца ва ўсёй яго творчасці, прасякае ўсе ўзроўні паэтыкі яго верша.

29 А. Мальдзіс, Выбранае, Мінск 2007, с. 124.

30 Пачьинальнікі. 3 гісторыка-літаратурньх матэрыялаў, укл. Г. Кісялёў. 2-е выданне, Мінск 2003, с. 422. 
Францішак Багушэвіч - першь, хто найбольш поўна $і$ паслядойна выказаў наспелую патрэбу ў існаванні начьлнальнай літаратурь i эстэтыкі, ён быў ледзь не першым пісьменнікам, - пісаў класік беларускай літаратуры Максім Багдановіч, - які з'явіўся прапаведнікам усебаковага наџылянальнага адраджэння беларусаў, даказваючь, што яньи прадстайляюць асобь, самастойны народ ${ }^{31}$.

Выдатны беларускі філосаф, літаратуразнаўца, культуролаг Уладзімір Конан на адной з канферэнцый, прысвечаных асэнсаванню беларускай нацыянальнай свядомасці, лапідарна-дакладна акрэсліў сутнасць галоўнай яе кампаненты: Нацылянальная ідэя - духойна-творчь аналаг гістарычнага быция народа ў трох вымярэннях - мінуйшчыне, сучаснасиі і будучыні. Кожны этнас, які вылявіу свае творчыя магиьмасиі і сфармаваўся ў начыю, увасабляе сабой пэўную ідэю ${ }^{32}$.

У нацыянальнай ідэі звычайна выдзяляюць наступныя прыярытэты: па-першае, любоў да гістарычнага мінулага і творчага дзеяння сваёй нацыі, сваёй мовы, свайго краю; па-другое, веру ў духойныя сілы свайго народа i, па-трэцяе, імкненне, волю да таго, каб свой народ быў годным членам у сям'і народаў свету ${ }^{33}$.

Нацыянальная свядомасць, ідэя адлюстройвае супольныя і агульнанацыянальныя інтарэсы ўсяго народа. Яна з'яўляецца, з аднаго боку, своеасаблівым генератарам жыццядайнай энергіi этнасу на шляхах пошукаў формы самавыяўлення, а з другога, у працэсе гэтага, часта змагарнага, пошуку сама ўмацойваецца, эвалюцыяніруе.

Гісторыя станаўлення, фарміравання беларускай нацыянальнай ідэі знайшла яскравае выяўленне ў даследаваннях беларускай літаратуры XIX стагоддзя. I можна сказаць, што літаратуразнаўцы па-свойму апярэджвалі сацыяльныя змены ў грамадстве. Менавіта даследаванне заканамернасцей развіцця прыгожага пісьменства адкрывала магчымасці асэнсавання шляхой фарміравання нацыянальнай ідэі ў XIX стагоддзі.

31 М. Багдановіч, Збор твораў. У 2-x maмах, Мінск 1968, т 2, с. 230.

32 http://nashaziamlia.org/2006/04/23/58/.

33 А. Астапенка, Нацьянальная ідэя ў сучасньл свеце, Мінск 2003, с. 156. 
S T R E S Z C E N I E

\section{DROGI TWORZENIA IDEI NARODOWEJ W LITERATURZE BIAŁORUSKIEJ XIX WIEKU}

Artykuł jest poświęcony kształtowaniu się idei narodowej w okresie formowania nowej literatury białoruskiej (XIX w.). Konsolidacja etniczno-kulturalna ludu białoruskiego, kształtowanie się zrębów nacji białoruskiej, charakteryzujące się powrotem do historycznych korzeni narodowych, kultury i języka ojczystego przebiegało w trudnych warunkach społecznych i politycznych. Przywrócenie pamięci historycznej i duchowej spuścizny narodu białoruskiego było wyraźnym impulsem dla pisarzy, a ich twórczość z kolei kształtowała ideę narodową, świadome dążenie do „stania się narodem”. Poszerzone o dotychczas jakby „niczyje” teksty badania literaturoznawcze otwierały nowe możliwości wyznaczania kierunku kształtowania się idei narodowej.

Słowa kluczowe: idea narodowa, świadomość narodowa, tradycja literacka, literatura białoruska XIX wieku, odrodzenie narodowe, białoruski kanon kulturowy, język białoruski, folklor.

\section{S U M M A R Y}

\section{THE WAYS OF FORMING NATIONAL IDEA IN BELARUSIAN LITERATURE OF THE 20TH CENTUR}

The article is devoted to the forming process of national idea in Belarusian literature (20th century). Ethnic-cultural consolidation of Belarusian people, shaping of Belarusian nation proceeded in rough conditions. The restoration of historical memory and spiritual heritage of the Belarusian nation was a clear impulse to writers whose literary works shaped national idea, conscious striving for becoming a nation. Literary studies extended by so called nobody's texts opened new possibilities to set new directions in the field of national idea.

Key words: national idea, national consciousness, literary tradition, Belarusian literature in 20th century, national rebirth, Belarusian cultural canon, the Belarusian language, folklore. 